\title{
Women's Empowerment: power to act or power over other women? Lessons from Indian microfinance ${ }^{1}$
}

Isabelle Guérin, Research Unit "Development and Societies" (Paris I La Sorbonne University / Institute for Development), associated to the French Institute of Pondicherry and to the Center of European Research in Microfinance.

Santhosh Kumar, French Institute of Pondicherry

Isabelle Agier, Research Unit "Development and Societies" (Paris I La Sorbonne University / Institute for Development), associated to the Center of European Research in Microfinance.

\section{Abstract}

In the microfinance industry 'empowerment' is often described as a means to facilitate female emancipation from male domination. This paper draws on women's testimonies to highlight the fundamental importance of women's relationships with one another in this process,. Women continuously negotiate a position between their kinship groups and neighbours, in a context where dependence on men is considered natural. Micro-credit uses are shaped by, and embody, relationships between women, including power relationships. We recommend revising current understandings of female agency to take into account the complex relationship between agency and power, and challenge the conventional polarity of power as domination (power over) and power as agency (power to). In many cases, even where there is solidarity between women, women having agency requires or implies domination over other women.

Key words: Microfinance, Gender, Empowerment, Power, Domination, Agency, India JEL codes: O16, G21, L31, J16, D14, D74, O53

\footnotetext{
${ }^{1}$ This paper has been supported by funding from the French National Agency for Research (ANR) within the RUME project (www.rume-rural-microfinance.org).This paper was initially presented in the conference Microfinance's Contribution to Development Studies: What Interdisciplinary Approaches Add to MicrofinanceUnderstanding? CERMi/UniversitéLibre de Bruxelles/Oxford University, Bruxels, January 2010. Comments from participants in the Conference and subsequently from James Copestake, Susan Johnson and Ariane Szafarz are gratefully acknowledged. We also sincerely thank the three editors of the special issue and two anonymous reviewers for their very useful comments.
} 


\section{Introduction}

The microfinance industry has developed alongside a liberal and individualist conception of women's agency,,understood as the ability of women to pursue their own interests, despite the pressures of custom, transcendental will or patriarchy. In facilitating access to financial services, self-employment and joint liability, microfinance is supposed to promote women's collective action and female financial autonomy In an echo of the liberal humanist tradition, female solidarity and emancipation from tradition and religious and male dominance are seen as desirable, and as valuable indicators of women's agency and 'empowerment'. But feminist scholarship has pointed to the discrepancies between normative prescriptions and actual practice, in policies and programmes (Cornwall et al. 2007), Professed intentions, which oversimplify women's relationship ties and the multiple ways in which the subordinated category of 'women' is constructed (Mahmood 2005; Mohanty 1988; Mouffe 1995). Feminist scholarship also challenges the orthodox definition of agency as "actions governed by selfdetermined goals and interests", highlighting the relational and gendered dimensions of women's actions (Ciotti 2009; Cornwall 2007). This article uses a case study of women's selfhelp group activity in rural southern India to contribute to these debates, exploring the relational dimension of women's agency: the subjective, multiple and conflicting meanings of women's empowerment and women's power, and the ambiguous role of relationships between women in this.

Over the past decade there has been debate as to the impact of microfinance on women's empowerment. While the development industry as a whole has long claimed a positive link, empirical evidence has been much more mixed (Armendariz \& Labie 2011; Armendariz and Morduch 2005). Some studies give positive findings, as measured through indicators including access to consumption, health care and contraception, improved decision-making power, better spatial mobility, access to property, and a decrease in domestic violence (Pitt and Khandker 1996; Hashemiet al. 1996) while randomized studies give negligible results (Banerjee \&Duflo 2011). In contrast, other studies have pointed to a number of negative consequences, both within households and on a wider scale, such as male control over the loans and/or women's businesses (Montgomery et al., 1996, Garikipati 2008; Goetz and Gupta 1996; Rahman 1999), increases in domestic violence and patriarchal domination through control by loan officers (D’Espallier et al. 2011; Rahman 1999), heavier responsibilities, workload and fatigue among women (Akerly 1995), disparate treatment of men and women in the conditions for loans(Agier 
Guérin I. Kumar S. Agier I. Women's empowerment: power to act or power over other women? Lessons from Indian microfinance, Oxford Development Studies, 41(1): S76-S94.

and Szafarz 2010), the exacerbation of inequalities among women (Guérin and Palier 2005; Mayoux 2001; Pattenden 2010; Rankin 2002; Rao 2008, Wright 2006), increased financial vulnerability and over-indebtedness (Olsen and Morgan 2010, Guérinet al. under review), and the confinement of women to low-productivity sectors (Fernando 2006, Weber 2006).

It is clear from the literature that the role and impact of microfinance in terms of female empowerment remains controversial. It is also clear that the controversies stem as much from the results themselves as from the methodologies and indicators used. Besides a diversity of contexts, gender regimes and microfinance methodologies, which clearly partially account for these mixed findings, this could also be due to the fact that people are not talking about the same thing (Kabeer 2001). Who defines the meaning and significance of empowerment, and on behalf of whom? Which indicators matter, and why? Definitional choice is of course anything but neutral, and necessarily embedded within wider theoretical frameworks.

As has been argued (Kabeer 2001; Johnson 2005; Mayoux 2001), instead of merely considering outcomes, we must also examine the processes and meanings of micro-financial practices. First, how do women themselves define and make sense of empowerment? Second, how are micro-financial practices and empowerment processes [particularly those related to gender] embedded within local institutions? The contexts of micro-financial practices can shed light on women's varying potential to benefit from its services. These are influenced by class, caste, location, religion, gender norms and individual differences (e.g. personal profiles), as well as the cooperation of husbands and support from kinship and other social networks.

By offering a comprehensive analysis, the three studies outlined above (Kabeer 2001; Mayoux 2001; Johnson 2005) have considerably enriched our understanding of the complexity and contradictions of empowerment processes., which contrasts with many studies which engage in static analysis and assume that empowerment is a smooth, homogeneous and linear process. Our own work has been much inspired by the former findings and we follow similar theoretical lines:contextualising empowerment as a concept, and considering its processes and meanings in a precise context. Our work differs from them in paying particular attention to relationships between women, which we consider to be a fundamental factor in women's agency and empowerment.

It is not entirely new to consider power and conflict relationships among female micro-credit clients, particularly in South Asia. Aminur Rahman has revealed how female borrowers in Bangladesh have physically attacked small businesses developed with micro-credit schemes, 
Guérin I. Kumar S. Agier I. Women's empowerment: power to act or power over other women? Lessons from Indian microfinance, Oxford Development Studies, 41(1): S76-S94.

either out of jealousy or when women borrowers have failed to return loans on time (Rahman 1999: 57-82). In southern India, three recent studies have clearly shown that caste and class relationships influence micro-credit outcomes, women from low castes and low classes being either excluded from or unable to make effective use of self-help group schemes (Garikipati 2008; Pattenden 2011; Rao 2008).

Our paper goes beyond the existing literature to further analyse the ambiguity of women's relationships with a focus on local subjectivities. How do women define, perceive and experience "empowerment"? We believe that this is the only way to understand the multiple and often unexpected ways in which women use microfinance programmes. We argue that relationships between women are indicative of women's subjectivities and agency, defined here as the capacity to act. From our work on women's narratives and testimonies, we present the following findings.

First, we highlight the subjective factors underpinning empowerment and its specific meanings in the context studied here. The women in our case study have varying religions, occupations and castes (with a mix of Dalits [ex-untouchables] and non Dalits). We find that patriarchy is characterized by strong male domination [although this varies with caste and class] and also by ambiguous relationships between women where solidarity, competition and rivalry coexist. Regardless of social standing, we find that women's primary goals within the household and as regards men seem to be more a matter of status, dignity and respect than of power per se. Power is sought, but this is expressed mainly in relation to other women, both within kinship groups and among neighbours.

Second, we describe the many ways in which women experience micro-credit. Our findings align with previous evidence on how women access and use micro-credit. But women's biographies also highlight the critical role of women's positioning in kin and neighbourhood hierarchies, including female ones: these networks frame and are framed by micro-credit use. Far beyond self-employment, the effects of which are negligible here [and restricted to nonDalits] the most visible effect is that local women leaders can establish themselves and consolidate their positions, including among Dalits. Controlling other women's loans or time seems to be a requirement for female leadership.

Third, and in line with recent feminist scholarship, our empirical findings suggest the need to reassess the meaning of women's agency (Abrams 1999; Ciotti 2007; Kabeer 2001; Mahmood 2005). They also suggest a challenge to the usual opposition between power as domination and 
power as agency. In microfinance debates, and more broadly in development studies, empowerment is frequently understood as the capacity to think and to act, in contrast to a conception of power as domination (Béteille 1999; Rowland 1995). While the distinction between these two interpretations is certainly useful, our observations suggest that a full understanding of empowerment processes should take into account the interactions between these two forms. In many cases, even where there is solidarity between women, women having agency requires or implies domination over other women.

\section{Methodology}

Our study is based on field work carried out in rural Tamil Nadu (Southern India), where microfinance has developed considerably over the past decade, both in quantity (Fouillet 2010; Srinivasan 2009) and institutional and ideological diversity (Augsburg and Fouillet 2010; Hudon 2008). The microfinance industry in Tamil Nadu focuses on women, who account for around $95 \%$ of the clientele, and rural areas, and mainly uses the "Self-Help Group" model (Sa Dhan 2009). SHGs consist of fifteen to twenty people who collect savings and then give each other small loans, who are then eligible for external loans. With active public policy and multilateral agency support, SHGs in Tamil Nadu have experienced unevenly distributed rates of growth since the early 2000s. In March 2009, the outstanding credit of the local microfinance industry was estimated at 463.4 million Indian rupees (INR), or 7.7 million euros; of which $74 \%$ was disbursed under the SHG model. It is also estimated that 730,092 SHG were created (Sa Dhan 2009).

Fieldwork was conducted in villages in two districts of North Tamil Nadu (Thiruvallur and Vellore). This was carried out in partnership with two microfinance NGOs, selected first for having provided microfinance services for over five years, and second for their interest in research collaboration. Our analysis draws extensively on women's narratives and testimonies, and combines various qualitative methods of data collection. First, we used semi-structured interviews with women and men, from (?) SHG members and NGO staff. Second, case studies and group discussions (again with women and men separately) were organized around specific topics including the concept of empowerment, intra-household relationships, kinship relationships, theorganisation of ceremonies, entrepreneurship, and financial practices. Group discussions were useful [and sometimes unavoidable given that people often wanted to participate in the discussions] in understanding official discourses, social norms and acceptable practices. Third, informal discussions and immersion in local daily life were instrumental for analysing women's trajectories. One of the authors lives in Chennai and spent a great deal of 
time in the villages. Since 2004, excellent relationships have been established with around fifteen women. They were chosen on the criterion of diversity and for their willingness to spend time with us. Proximity and follow-up over a long period of time allowed us to reconstruct what amount to "life histories", understood here as the discursive product of multiple iterative interviews which takes the form of a narrative. Such narratives stand out from other types of investigation as the sole means of perceiving the dynamic dimension of personal lives. Repeated visits over a five year period also allowed us to capture the ongoing experiences of these women, and in some cases to follow processes of change. Finally, observation has been a key tool in analysing and interpreting the nature of social interactions between women, both in the home and the wider community. This revealed the fundamental importance of honour, status and dignity, but also how kinship and neighbourhood positions are fundamental to women's self-perception of status.

This qualitative research was complemented in 2008 by a survey, based on a questionnaire,of 170 women clients of both NGOs. The purpose was two-fold: first, to get a description of the main socioeconomic characteristics of the population served by the NGOs and second, to quantify certain traits identified in the qualitative research.

The sample, collected in order to get a representative picture of the population ${ }^{2}$ covered by the NGO, sheds light on the heterogeneity of the women. Sixty per cent of the women are Dalits (former untouchables, here mainly Paraiyars), while forty per cent are "caste Hindus" (mainly Vanniyars, and few Mudaliars and Naidus) ${ }^{3} .10 \%$ of Dalits have converted to Christianity. As we discuss later, this may be an advantage to them in terms of accessing specific networks, but their social identities and rank in local hierarchies do not change as a result of their conversion. Women interviewed ranged in age between 18 and 55 with an average of 35 years. One third (32.9\%) have no education. Half of them do not have any income-generating activity. Twothirds of women earning an income work in agriculture (almost exclusively as daily labourers) and the remaining third in non-farming activities (including $13 \%$ self-employed).

\section{Empowerment subjectivities}

We can see from women's narratives and lived experience that local patriarchal norms vary and have common points, namely women's dependence on men[albeit to varying degrees] and

\footnotetext{
${ }^{2}$ We used a random sample stratified by proximity to the city and caste.

${ }^{3}$ In the paper we point out differences between Dalits and Hindu caste women (or non Dalits), though it would also be necessary to explore differences within non-Dalits.
} 
the central role of women's relationships with one another in the household, among their kin, and in their neighbourhoods.

\subsection{Local terminologies: empowerment and agency}

Looking at local terminologies provides a first understanding of women's subjectivities. NGO staff sometimes usethe English term "empowerment", but very few women are familiar with it, and even among the NGO staff many people struggle to define it. In official communication (e.g. training and public events), the transliteration most frequently employed is the word "freedom", a broad concept which is then broken down into: "economic independence", "equal rights" and the capacity to "act". Numerous discussions that we held with the women themselves to try to define "their" conception of empowerment raised the following issues. The first is one of a normative horizon: the ability to manage alone even in the event of abandonment, desertion or separation from the family of origin. In a context where kinship ties ensure security both materially and in terms of social identity, such scenarios are obviously undesirable ${ }^{4}$. Nevertheless, some women consider that in an ideal world there would be the potential for emancipation from all such bonds of dependence. In relation to the request to provide more realistic objectives, answers given show more diversity and focus on opportunities to take action. The women speak of seizing "opportunities", to have "freedom of movement", to show "courage", and to exercise "responsibility". Issues of "good reputation" and "good name" are also often raised. Here again these are normative ideals which are far from a given in practice, which the women are perfectly aware of. The NGOs also use these terms on a daily basis and encourage the women to be "courageous", "active and energetic", "strong", etc. The NGOs sometimes cross the line between encouragement and judgement (much too often in the eyes of the women). Many of them state that the NGOs' blindness can irritate and at times exasperate them. "We are drowning, and they want us to learn how to swim," stated one of them to illustrate the discrepancy. Owing to the many restrictions they face, some women suggest defining empowerment quite simply as the ability "to solve problems" and "to manage suffering".

While most women use similar terms, the content of actions varies greatly and this depends both upon households' positioning in local hierarchies and singular circumstances. Dalit women and those from the poorest families face higher material constraints [they more often

\footnotetext{
${ }^{4}$ Of the 170 women questioned, none are divorced and one lives separately
} 
Guérin I. Kumar S. Agier I. Women's empowerment: power to act or power over other women? Lessons from Indian microfinance, Oxford Development Studies, 41(1): S76-S94.

work and contribute more to household incomes ${ }^{5}$ ] while enjoying greater freedom of movement._Male control over women's movements remains a strong indicator of social hierarchy, and therefore a preserve of upper castes ${ }^{6}$. For some non-Dalits caste women, the very fact of talking to us was an indicator of empowerment, while for most Dalits, talking with "foreigners" ${ }^{7}$ was routine. Diverse patriarchal norms are a matter of conflict amongwomen. Many Dalit women are proud of their (relative) freedom, stating that they are poor but not 'slaves', and are less afraid of men. Conversely non-Dalits are proud to say that their husband "protects" them.

It is also worth noting that normative discourses on empowerment may be a source of exclusion. As observed elsewhere (Mayoux 2001), the poorest and those who lack social relationships are excluded, but conflicting values are also a source of self-exclusion, either on women's own initiative or through their husbands or in-laws.

\subsection{Dependence on men and "unequal interdependence"}

Even at the bottom of the hierarchy however, women's autonomy remains limited and dependence upon men is the rule ${ }^{8}$. Even for Dalit women, the simple fact of talking about power makes most women nervous. They often wonder how they are to talk about power when they are always controlled and constrained in their decision-making. But dependence should not be seen solely as a matter of male domination, and here lies the ambiguity of intrahousehold relations, which are characterized by a continuous combination of "conflict and cooperation"[here we use the terms of economic theory], and by "unequal interdependence" (Kabeer 2001). Many women are perfectly aware of the extent of their subordination and their limited access to resources, decision making, rights or respect. Most are also adamant as to

\footnotetext{
5 In our sample, Dalit women work more frequently than the others (57\% as opposed to $40 \%)$. Wives' contributions to household income are higher among Dalits than non-Dalits, both in absolute and relative terms. On average women's annual income is 10,153 INR for Dalits as opposed to 8,335 INR for caste Hindu women. Women's income amounts to $17.8 \%$ of household total income for Dalits (out of a total income of 35,741 INR) as opposed to $9.6 \%$ for non-Dalits (out of a total income of 41,563 INR). Some female breadwinners were found among low Dalits, but not among non-Dalits. We note however, that women's contributions to household expenses are much higher than their contributions to household income, as their income is usually devoted to the household's well-being, while men often spend part of their income on personal expenses and helping their own kin.

${ }^{6}$ For an analysis of diversity in gender regimes on class and caste lines in Tamil Nadu and the relative freedom of Dalit women, see for instance Heyer (2012), Kapadia (1996), Krishna (2005), Ravindran (1999).

${ }^{7}$ Foreigners are white people, but also Indians coming from the city (as one of us).

${ }^{8}$ Although the relative freedom of Dalit women is often highlighted, Dalits are not free from patriarchy (Rao 2003 quoted by Ciotti 2009). It is clear however that in other places in rural Tamil Nadu, Dalit women enjoy much more freedom than the context studied here (see for instance Heyer 2012).
} 
male shortcomings as breadwinners. For example, the subject of male "laziness" frequently underpins daily preoccupations and discussions. Not only are men criticised for working on an irregular basis (some very little), but women often also complain that men keep most of their wages for personal use (for instance to procure tobacco and alcohol, and also to assist their own kin $)^{9}$. Yet the honour and reputation of the family remain linked to the ideal of man as a dominant decision-maker. "If the men do not have 'control' we [the women] are not respected", women often say and Dalit women are no exception. "The reputation of my husband is mine and vice versa" they also often say.

Aside from such discourse, our observations of daily practices, talks between neighbours and our involvement in close discussions with those to whom we developed close ties, show the extent to which the desire for respect and dignity influences women's rationale, tactics and strategies. "How can we be free and powerful when we don't have respect?" was often asked. Besides the material hardship of hard work, domestic violence and multiple deprivations, there is no doubt that disrespect, humiliation, and contempt are the primary sources of women's suffering. Verbal violence is often experienced as more hurtful than physical violence. This can for instance involve being branded as incompetent, a bad wife/mother/daughter-in-law (unfit for "family life" is the most common expression), or as a prostitute, this being a very frequent insult at times when women are in contact with men outside the family, whatever the reason.

\section{3 Power over other women versus power over men}

In the context of this desire for respect, a fundamental role is played by relationships between women. Different forms of female relationships should be distinguished. First come relationships with the husband's kin. In our sample most households are nuclear (67\%) but patrilocal residence remains a rule. Only one quarter (25\%) of women still live in the village where they were born. Even when couples do not live with the husband's parents, houses are often adjacent. As a consequence, most women have no other choice than to cohabit with their husband's kin. Women's relationships with their in-laws involve some sort of cooperation (especially surrounding child care), affection and complicity. However as men spend most of their time outside, household spaces are primarily female spaces, in which conflict and rivalries are commonplace. Daily conflicts and tensions arise concerning the distribution of family duties (who does what), freedom of movement (women's mobility is limited by men but also

${ }^{9}$ As observed by Mencher (1988) in the 80's in other parts of Tamil Nadu. 
very often by elder women), strategic decisions (children's education, the organisation of ceremonies), and household budget management and resource allocation (who decides how much to spend and on what, whether for daily consumption, investment, or life cycle expenses such as social and religious rituals). Beyond daily cohabitation issues, conflicts and tensions also relate both to material and broader social issues. These include inheritance and property distribution, dowries, financial responsibilities for life cycle events (who pays for marriages or for funerals), or 'immoral'behaviour such as "love marriages", adultery, illegitimate children and alcoholism. Women are very often seen as responsible for male immorality.

Women describe the difficulties of this cohabitation with humour, but also great bitterness. Hierarchies are never fixed, but permanently bargained for and negotiated along various lines such as age, kinship ties (blood versus marriage ties), and the husband's position within the household, which is itself governed by age and economic power. Sisters and sisters-in-law often compare themselves on the basis of their husbands' contributions to the household income. Women are also judged and judge themselves for who they are and what they do. These judgments appear to be based on two main factors. The first is their capability to follow "feminine" norms. Some of these are visible and (implicitly) evaluated collectively: cooking talents, appearance, modesty and discretion. Others, for instance women's sexual capabilities, belong to private male knowledge. Many women say clearly that they "buy" their husband with sexual favours.

The second aspect is purely material: women's bargaining power depends upon their ability to contribute to the household budget. What needs emphasizing is the variability of women's financial contributions. Far beyond their own income (for those who work), women's contributions to household expenses depend upon the support they can get from their own kin, together with the relative importance of this support compared that of the husband's $\operatorname{kin}^{10}$. Expectations start at marriage withthe payment of a dowry, and continue throughout life, at times of financial crisis and life cycle events.

The responsibilities of the wife's kin are intended to compensate for the fact that women have no real access to inheritance and property rights ${ }^{11}$. Contributions from the wife's family play a

\footnotetext{
${ }^{10}$ However, and as suggested by NailaKabeer (1999), the importance of kin support is probably less prevalent in south India than in the North, where women's income is usually lower because of stronger patriarchal norms.

${ }^{11} 6 \%$ of the women declare having legal property titles for land, and 5.5\% for housing.
} 
Guérin I. Kumar S. Agier I. Women's empowerment: power to act or power over other women? Lessons from Indian microfinance, Oxford Development Studies, 41(1): S76-S94.

central role in women's recognition by their in-laws ${ }^{12}$. Such contributions regulate hierarchies between sisters-in law, women's movements (women are more often allowed to visit their own kin if they have a chance to return with gifts), and involvement in important decisions, especially ceremonies.

Relationships with other women also take shape within a neighbourhood context. Although women have little mobility outside their village, or even within their own neighbourhood given that villages are spatially segmented along caste lines, they have intense relationships with their own neighbours. Here too neighbourhood spaces are mainly female spaces, as men either work outside the village or meet in male-specific public spaces [tea shops, temples, political meetings, etc]. Here too solidarity, mutual help and support mix with status concerns, jealousies and conflicts. Owing to their spatial proximity, women spend much of their time monitoring and observing each other. Dissenting behaviour, or even suspicion, can lead to denunciation, threats, blackmail, and acts of connivance or complicity. Those who enjoy a little more freedom than others are controlled by the others who act as "evil eyes", we were often told.

At the same time, solidarity and cooperation are instrumental in helping women manage their household finances. Most participate in a variety of strictly female financial circuits (HarrissWhite and Colatei 2004; Guérin 2011), which include rotative saving and credit associations (which collect savings among their members and one member takes the whole sum once) as well as the reciprocal exchange of cash or goods, and especially food and jewels (gold) that women will wear during ceremonies or use to obtain cash from pawnbrokers. For instance in our sample $65 \%$ women regularly exchange jewels with their neighbours and $66 \%$ regularly borrow cash from them.

All women are not equal within these financial circuits, however (Guérin 2011). Some women content themselves with borrowing negligible sums from their immediate social and physical entourage, whilst others handle considerable sums in relation to their income, going to various places in order to meet lenders. The most active women play the role of intermediary for their peers. At the time of the survey, the average outstanding debt per woman was 10,337 INR (around $172 €$ at the time of the survey), ranging from 0 to 310,000 INR (around 5160€. Women who live in their place of birth enjoy better access to solidarity networks (77\% borrow cash

\footnotetext{
${ }^{12}$ In our sample, kin support averages 11,264 INR annually, the equivalent of 30\% household annual receipts. On average, $56 \%$ of this support comes from the wife's kin, but this ranges from 0 to $100 \%$. In more than half of households, the wife's kin contributes less than $23 \%$ of the kin's support, and in one third of cases they contribute less than $17 \%$.
} 
from their neighbours against $62 \%$ for women who have migrated). Caste and class hierarchies also determine the nature of female financial circuits. Dalit women are more involved in reciprocity neighbouring networks $(73 \%$ borrow cash from their neighbours against $56 \%$ for non-Dalits). They have more restricted access to the financial market (and so doDalit households): at the time of the survey Dalit women had an outstanding debt of 1,444 INR (24€) against 4,274 (71€) for non-Dalit women (household debt was respectively 6,313 (105€) and 16,372 (273€). Hindu caste women lend money to Dalit women, whilst the opposite scenario is very rare. Among Dalits, the better off (most often spouses of civil servants) lend money to their neighbours. As we shall see, SHGs rely on these pre-existent chains of debt, which they reinforce.

\section{Micro-credit appropriation: diverse and unusual pathways}

Most of the women are fully aware of the number and strength of their bonds of dependence, but this does not necessarily mean that they accept them or that they are unable to exert any form of agency. Most women clearly state that they have the will to take initiatives and action. Many also comment that SHG membership offers new opportunities to act. But their rationales, motivations and subsequent actions vary and are sometimes surprising. Notwithstanding caste and class hierarchies, relationships between women influence microcredit appropriation.

\section{1 Female entrepreneurship}

Although self-employment is often considered microfinance's central goal, in our case study such an outcome is negligible and mostly limited to non-Dalit women. According to our survey, out of 449 micro-credit loans reported, a small fraction(4.5\%) is intended for business purposes. Micro-credits are primarily used for health expenditure (22\%), children's education (16\%), housing $(14.2 \%)$ the financing of ceremonies $(15 \%)$, and repaying previous debts $(12 \%)^{13}$. Not only are few women self-employed, but the remainder are rarely interested in starting a business, as they are very aware of the risks. Lack of mobility and limited social networks prevent them from dealing directly with suppliers and even sometimes clients. Local demand is rather low and most markets are already saturated. Market segmentation along caste and class lines is an additional limiting factor (Harriss-White 2010; Prakash 2010).

\footnotetext{
${ }^{13}$ The survey aimed at quantifying the "main purpose" of the micro-credit. However money is fungible and microloans are usually used for a variety of purposes. What is clear however is that a great majority of micro-credit uses do not generate direct income.
} 
Case studies of fifteen women who started a business using micro-credit, and are considered as 'successful' by both NGOs, show that their rangeof experiences have striking similarities. Their businesses include small trade (groceries, clothing), handicrafts and tailoring, food processing and services located in small towns (catering, beauty parlours, photography workshops, internet centres) or exceptionally in villages (catering, oxcart transport). Caste and to some extent class largely influence the choices of activities, owing to social norms but also to know-how and networks. Of the 15 women, only one was Dalit. In the area studied, trade on a large scale,tailoring and services are easier for Mudaliars and Naidus, this being both a matter of experience and networks with middle-class clients. Small grocery stores are the most frequent activity for Vanniyars. Catering is often a privilege of upper castes, unless the clientele is restricted to the owner's caste. Dalit businesses (whether male or female) are restricted to illegal activities (e.g. sand extraction, local alcohol production, the black market sale of statesubsidized food items) or to minuscule grocery shops or restaurants in the colony (i.e. the part of the village where Dalits live $)^{14}$. Women's life-cycle positions also influence their involvement in business: of the 15 women, only one has young children and most of them have no domestic responsibilities. Beyond the burden of household responsibilities however, what matters is their positioning in the kin hierarchy.

In five cases, the businesses are family-run and managed by men (husbands, son, son-in-laws, brothers), women merely executing orders. In five other cases, women take most of the responsibilities, with the full support of their husbands, and possibly of other kin members. Echoing Manuela Ciotti's observations on women political leaders in northIndia (Ciotti 2009), we observe that husband and kinship cooperation, whether in terms of advice, moral support or extra financial assistance, is often a key supporting factor. But so are women's own motivation and their evaluation of their own empowerment, their position relative to their kin, and less commonly their husbands. Sometimes there is also clearly a degree of husband-wife solidarity in terms of standing up to kin, in-laws or perhaps children. A few examples can illustrate this.

We encountered two cases of grocery stores run by Vanniyarwomen along with their husbands. The first woman, Ponnamma, assesses her achievements in terms of her status in the local

\footnotetext{
${ }^{14}$ Whilst our narrow sample of course cannot be used to press claims of generality, these observations raise fundamental questions that go far beyond the scope of this paper as regards the inability of microfinance to promote self-employment. For similar observations on micro-credit and self-employment in rural Tamil Nadu, see Kalpana (2008). It is worthwhile noting that an evaluation of credit programmes for the rural poor in India, in particular the IRDP, led to similar conclusions. See for instance Dreze (1990). For similar results on the limited use of micro-credit for income generating activities see Collins et al. (2009).
} 
community - she is now a respected woman in the neighbourhood - but also as regards her inlaws. Her parents are from the same caste but are less well-off, which her mother-in-law, brothers and sisters-in-law regularly point out. She and her husband can now send their children to English school, and contribute significantly to the cost of family ceremonies. This, she says, proves that they are 'capable' and can 'stand on their own two feet'. The second woman, Shanthi, highlights that one of her motivations for starting a business was to "stand her ground with her son and daughter-in-law". The young couple refused to have them at their home, which she considers both a betrayal and an insult. Running a business, as small as it might be, is a way to have some financial independence and to maintain her dignity.

Saroja, who belongs to the Mudaliar caste, runs a photography studio with the help of her husband, who provides technical advice and assistance finding clients. Her business is not a matter of money, she says. She could afford to stay at home, as her husband works as a local administrative official. Here too, it is a matter of status with her in-laws: not only is running a studio a respectable business, but she considers the money she earns as "compensation for the low value of the dowry" she brought when she married.

The sole Dalit case is no exception to this scenario. Rajeswari takes micro-loans for her husband, who drives an ox-cart. Her husband's business and the fact that she is able to borrow to support him allows her to "prove her competitiveness [and her] strength" to her in-laws, who never accepted the fact that the couple decided to leave the extended family.

For the two women who started a business on their own, it is probably here that the effects are the most visible and tangible: earning money, leaving the village to buy materials, talking to officials and standing up to their husbands is clearly both a motivation and an achievement. But their biographies reveal intense stress and strains in their social relationships. Women face many problems and constraints when starting a business on their own, often in the face of opposition from kin. Most of these businesses are vulnerable and lack profitability. They also incur social costs, such as interminable working hours, and endless criticism from both kin and neighbours. For instance, a good businesswoman can easily be called a 'prostitute' in reference to her relationships with male suppliers and customers. This must then be compensated by irreproachable behaviour and increased acts of generosity to one's close circle, especially inlaws.

\section{2 Women's role in household finances}


In most cases micro-credit is simply used to improve household finances. As stated above, women already mix and match multiple financial instruments in order to make ends meet. Any additional source of cash is very much welcomed and seen as a means to loosen liquidity constraints, even if it means additional pressure (D'Espallieret al. 2011). The pressure is even stronger in these cases, as most micro-loans are used for purposes that do not generate direct income $^{15}$. Even when husbands or in-laws exert control or take over loans, the fact that women are the official beneficiaries helps them to negotiate in other areas afterwards - "it's a give and take policy" is often heard. In many cases, and as other studies on Tamil Nadu report (Kalpana 2008; Jauzelon 2007), group functioning is far from harmonious. The selection of loan beneficiaries and delays in repayment cause many disputes, which tend to revive pre-existing neighbourhood or intra-family disagreements (alliance or blood ties exist within many groups). The rise of some members, whether economically, socially or as group leaders, often stirs up envy and jealousy. Many groups have stopped meeting simply to avoid open conflicts. The leaders take care of the transactions and deal individually with each member. Competition and antagonism however, are not incompatible with financial solidarity. Women say they regularly exchange micro-loans (64\% of our sample), either giving part of their loan to another group member or repaying more quickly in order to allow others to benefit from their loan before the final repayment date.

Meanwhile the reinforcement of existing hierarchies between women is also likely as an outcome. As described above, women's financial management roles are extremely varied. Such diversity necessarily translates into various sorts of micro-credit appropriation. Women in our sample took 2.6 loans on average, the total ranging from 0 to 5 (some women are SHG members but never borrowed). One third of women took one loan, and half took at least 3 loans. SHG loans have an average value of 7,296 INR and can amount to 33,000 INR, but half the women in our sample borrow less than 5,000 INR and two-third less than 7,500 INR. However these figures under-estimate the unequal distribution of micro-credit, as some women frequently appropriate from others. Ultimately, some women are nothing more than puppets: they belong to an SHG on the request of their husbands or stepmothers, and content themselves with simply carrying out their instructions, whilst others have appropriated the system and gradually become local leaders. Not only do the latter play a decisive role in the coordination of their group, but they use their new responsibilities as a means to create or further develop their role

\footnotetext{
15 Of course improved access to finance is not without costs. In some cases it is likely that micro-credit increases women's financial fragility (Guérin et al. under review, Olsen and Morgan 2010).
} 
of money-lender, or as intermediaries and as a source both of income and a certain form of power. They help to access potential lenders, stand as guarantors, and sometimes travel and obtain sums themselves, forwarding advances to those struggling to repay their micro-credit on time. Here too, male support is instrumental. Though their engagement in SHGs often generates household conflict, most of these women leaders have understanding husbands. Women's positioning in kin and neighbourhood hierarchies, including female ones, come into play: micro-credit appropriation is both shaped by and constitutive of these networks. As for entrepreneurship, kin relationships act as a resource. Some, although not all SHG leaders, delegate domestic chores to kin members, sometimes as a form of motivation: leadership and its resultant tangible and intangible benefits are a way to socially position themselves and win their kin's respect. Furthermore, most leaders use their position to actively participate in local patronage networks, which remain the dominant form of access to resources in rural India ${ }^{16}$. Here the prerequisite is to 'control' other women: sometimes their loans, but above all their time. These women leaders build their legitimacy by offering multiple services to other women, but also by their ability to mobilize people for NGO meetings (training, sudden visits from funding bodies or officials), or to political party mass events, to which both NGOs studied here are strongly linked. Their mobilisation skills help them to access powerful networks and hence resources. Few are politically active, and in general they engage with politics indirectly by forming alliances with local political leaders, most of whom are male. While it is beyond the scope of this paper to look at the diversity of networks women leaders are engaged in, what we shall however note is the importance of Christian networks: one of the two NGOs is Christian and has established privileged relationships with some Christian women. The following example highlights the ambiguity and complexity of women's relationships, how they facilitate and restrict action but also motivate decisions, and in turn how they evolve with the emergence of leadership. Saraswathi considers herself the main decision maker of her household, but she constantly feels strongly pressured by her in-laws who live nearby. Her marriage was a "love marriage" and she considers that her in-laws always use this as an excuse to scold her. She shoulders considerable financial responsibility for her in-laws, helping them whenever they need cash (especially for ceremonies), helping them find lenders and sometimes even fully managing the transaction. In the neighbourhood many women also consider her as a resource, as she "helps" with many things. She does not charge for this kind of assistance, but obtains indirect benefits, the first being improved creditworthiness among local lenders and better

\footnotetext{
${ }^{16}$ For a review, see Pattenden (2011).
} 
Guérin I. Kumar S. Agier I. Women's empowerment: power to act or power over other women? Lessons from Indian microfinance, Oxford Development Studies, 41(1): S76-S94.

borrowing conditions. "Respect" and "gratitude" from local women is another indirect benefit. She also states that she can "control" them. For instance she can easily mobilise them for mass events (political meetings, public events organised by the NGO, etc.). This in return helps her to negotiate additional resources (governmental schemes, loans from various sources) and to obtain better access to administrative services (at the time of our last visit, we saw her helping neighbours to approach the District collector about a problem with a property title). She does this both for her household, her kin and her circle of favourite women. She has been an SHG leader since 2004, and fully controls not only her own loans, but also those of her daughter and her sisters-in-law. Clearly SHG membership has helped to strengthen her financial position, both among her kin and within the local community.

The ways kin members react to women's leadership vary greatly, from cooperation to indifference and open conflict. Saraswathi's case is therefore not the rule. What is typical, however, is the way she uses "her" group to position herself within local networks of patronclient ties. Most SHGs have seen the emergence of one or up to three women lenders. Some were already in a position of local leadership, while for others SHGs offer new opportunities. In all cases, the (relative) control they exert on monetary flows, and the members of groups and the multiple services they offer, allow them to participate in local circuits of wealth distribution.

\section{Analysis: reconsidering agency, power and empowerment}

Women's narratives and personal experience offer insights into the complex web of power relations within which gender remains embedded. Not only is women's identity and diversity of positioning constitutive of pre-existing inequalities and hierarchies between women, but it also shapes dynamics of mobility, exclusion and marginalisation. This includes access to and use of development programs, including microfinance. Women's narratives also shed new light on women's agency, on the intricate relationships between agency and power, and subsequently on the concept of "empowerment". First, for most women who we met, gaining respect and status within the household and among kin were obviously major motivators. As observed in other contexts, those seeking economic and financial independence rarely do so as individuals but as conjugal units, striving for independence from their in-laws or children (Ciotti 2009; Cornwall 2007). Women's attachment to the conjugal unit is of course shaped by social norms and structural constraints, in particular women's dependence on men. Given that such actions often require adherence to patriarchal norms, should we consider them as agency, 
as local women do? This would go strongly against a conventional feminist framework, in which patriarchal norms are conceptualized in binary terms as either consolidation or subversion. In line with Saba Mahmood, we recommend moving away from a dualistic framework to consider the variety of ways in which norms are "performed, inhabited, and experienced" (Mahmood 2005: 22). In line with Foucault and Butler, Mahmood invites us to consider norms not only as something imposed on the subject, but which constitutes the subject. Agency should not be seen only as a synonym for resistance to relations of domination, but "as a capacity for action that historically specific relations of subordination enable and create" (ibid. 18). Only by adopting a broad, open vision of agency situated within particular historical and cultural contexts can we understand how women understand, translate, appropriate and sometimes subvert development programs.

Second, relationships between women are fundamental both in determining each woman's social position, and in how they make use of micro-credit. Over the last thirty years feminist scholars have considerably enriched our understanding of the household, especially by highlighting that extensive conflicts and pervasive cooperation can coexist in household arrangements ${ }^{17}$. However the issue of female relationships within household bargaining processes has attracted little attention. It is of course well known that patriarchy is characterized not only by male domination but also gerontocracy (Kandiyoti 1988). It is also recognized that kin support and women's networks are instrumental in helping women to defend their "fallback position" (Agarwal 1994), and this is a strong argument in favour of female collective action. However the nature and the diversity of female relationships have garnered very little attention (Cornwall 2007). As for intra-household relationships between women and men, women's spaces should be characterized as sites of both "cooperation and conflict" as well as of asymmetries of position. These two aspects make them particularly complex.

The ambiguity of female relationships demands reconsideration of the current debates on power within the field of gender and development studies. Academic debates on power usually posit two definitions, often thought as contradictory. The first defines power as getting someone else to do what you want them to do ('power over'). Power is conceived as a relation of domination and subordination, as a zero-sum game and as a conflicting process: those who get power necessarily get it at the expense of others ${ }^{18}$. The second conception considers power

\footnotetext{
${ }^{17}$ For a review see Razavi (2010).

18 This conception of power is in the continuation of Max Weber or Michel Foucault, who consider power primarily as a relationship and as a confrontation between two adversaries. See for instance Foucault (1983).
} 
as an ability or capacity to do something ('power to') ${ }^{19}$. Various forms of feminist theory have significantly elaborated the second definition, arguing that power conceived as power-over, domination, or control is implicitly a male conception of power (Allen 2005). They ask for a re-conceptualization of power as a capacity, ability or agency: people are empowered when they develop a better ability to define their goals and act upon them. It is the second definition which is usually used to define, justify and analyse projects which aim at empowering women (Rowland 1995). This invites two comments. First, it barely considers the idea that women would deliberately use development programmes (here, microfinance) to dominate other women. We have seen that this does however take place, not necessarily because 'power over' is an objective in itself, although this scenario certainly exists, but also because some forms of action require some form of power over. 'Power to' is limited by various constraints, including interdependency between individuals. Individual agencies are interconnected, interdependent and sometimes in contradiction to one another. If $\mathrm{X}$ takes action $\mathrm{A}$, it can prevent $\mathrm{Y}$ from taking action B. As the women's narratives above indicate, female agency encompasses two main types of actions: decision-making and seeking respect and status ${ }^{20}$. However in many cases, decision making as well as status are not infinitely expandable. Status is meanwhile a relative notion. Women's status depends upon their relative position as regards other women, both within their household, kinship and neighborhood. Theoretically one of the purposes of microfinance is to promote the status of women as a whole, as a category. However as long as this does not occur - which is very much the case here and which would require much more effort than micro-loan provision alone - the issue of status remains an individual one, based on comparison and hence implicit competition between women. All of the women we met who felt that they improved their standing within their kin and neighbourhood in recent years through participation in micro-credit schemes, did so in a way demanding some form of control over other women, and /or a degradation of status amongst other women. As Cornwall (2007) points out, the common belief that women's leadership would be different to men's, more altruistic and more oriented to civic engagement, deserves to be seriously questioned.

In other words, 'power to' may involve a certain form of 'power over'. This type of 'power over' is relative in the sense that it takes place mainly amongst women themselves. Women do not seek to challenge the hierarchical order of female subordination. Though many of them are perfectly aware of their material and ideological dependence on men, they have internalised

\footnotetext{
19 This conception of power can be found in the work of Thomas Hobbes or Hannah Arendt.

${ }^{20}$ Our observations echo to NailaKabeer's framework on empowerment (Kabeer 1999).
} 
Guérin I. Kumar S. Agier I. Women's empowerment: power to act or power over other women? Lessons from Indian microfinance, Oxford Development Studies, 41(1): S76-S94.

such structures, seeking to make their position in the pre-existing framework more comfortable rather than challenging the framework itself.

\section{Conclusion}

Over the past few decades the idea of "female empowerment" has been at the top of development agendas, resulting in multiple and often contradictory discourses on gender and development. Visions promoted by radical philosophies of feminist activists, for instance, have little to do with the more individualised sphere of self-help politics. Very little attention however, has been paid to how specific empowerment discourses are perceived by those constituted as the "beneficiaries" of such programmes. This under-theorization of microfinance as a "lived experience" means that the wide range of complex and often surprising processes through which the concept of empowerment is received, appropriated, accommodated, and sometimes challenged have often been overshadowed. In an effort to explore how women make microfinance their own, this paper has analysed how women take socially embedded critical perspectives towards empowerment, and how the idea of "women's empowerment" is given meaning through women's situational constraints, aspirations and expectations.

Our findings do not claim any generality. Gender relations are historically and socially constituted and it is likely that women's perceptions of empowerment vary accordingly. In certain contexts, as is the case here, women are not necessarily looking for autonomy and independence from men, but rather for respect within their own community (Basu 1995; Kabeer 2001; Ciotti 2009; Cornwall 2007). However, far beyond the specificity of the context studied here, and from a theoretical perspective, our case study highlights the need to explore the diversity and complexity of relationships between women. Gender relationships are often reduced to relations between men and women, and possibly to relations between older and younger women. Yet it would seem that the kind of relations that shape women's daily lives, well-being, expectations and behaviour, mainly concern relationships between women (Cornwall 2007).The domination of older women over younger women, often stressed in the literature, is only one aspect of these relationships.

Our case study also highlights the need to go beyond the basic opposition between power defined as domination versus agency, and analyse in more detail how these two dimensions of power interact. We have observed that discourses on women emphasise a conception of power as agency. Yet insofar as women's status is dependent on their husband's position and on women's relative standing in relation to other women, both because of cultural ideologies and 
material constraints, 'power to' necessarily implies a certain form of 'power over', this mainly over other women. In other words, in some cases women's empowerment - at least according to their own definition - might translate into the disempowerment of others.

Examining "agency from below" is also instructive in terms of wider structural factors of inequality and oppression. As Yogendra and Rankin (2010) argue, the subjectivities, consciousness and experiences of power of microfinance programme participants have something to tell us about the structural constraints that shape the practical outcomes of development programmes. Highlighting the existence and importance of hierarchies between women is not a question of underplaying female subordination; rather the opposite. In our research, women's experiences of empowerment highlight the contradictions between individual trajectories and structural constraints. All things being equal, it is in women's best interests to compete with other women. Ongoing conflicts, rivalries and competitions between women arise partly through their status as subordinate.

These findings have key policy implications. In terms of microfinance, they confirm a number of scholars' existing claims that microfinance alone has little chance of challenging gender hierarchies, ${ }^{21}$ or that it may even exacerbate pre-existing hierarchies, in particular inequalities between women. A further implication relates to a long-standing debate in the field of gender and development as to the ambiguous and often conflicting relationships between women, individual agency and feminist collective struggles, and furthermore about the multiple and contested meanings of "feminism" itself (Molyneux 1985). Divisions between women raise a thorny dilemma for both development and feminism: "that of how 'women' come to be represented, and by whom"? (Cornwall et al. 2007).

History tells us that collective action has always been instrumental in promoting the rights of marginalised groups, and women's rights are no exception ${ }^{22}$. But history also shows the fascinating diversity of feminist activism, whose struggles and concepts are shaped by and engage with various forms of power. Given the diversity of gender regimes and forms of power within which women's agency is embedded, and the multiplicity of women's aspirations, constraints and struggles, imposing agendas of reform from above or outside would be doomed to fail. Therefore to suggest concrete measures of action is not only impossible, but also not

\footnotetext{
${ }^{21}$ See for instance Fernando (2006), Johnson (2005), Johnson and Rogaly (1997); Mayoux (1999), Servet (2006) For India, see Garikipati (2008), Rao (2008).

22 See for instance Agarwal (1994) for women's property rights, or Kabeer (2010) for women's right to work and for social protection.
} 
our place. All we can do here is to urge an open, broad vision of the concept of agency (Ciotti 2009; Mahmood 2005) and to highlight the risks of substituting agency with the liberal ideal of autonomy (Abrams 1999; Mohanty 1988), which many development activists, and microfinance advocates in particular, implicitly promote. This does not mean that normative prescriptions are unnecessary. The concept of empowerment should still be seen as a process of social change for greater equality. Transformative agency, which has the potential for challenging and destabilizing inequalities, should be distinguished from forms of agency which merely express and reproduce inequalities (Kabeer 1999). A broad view of agency however is needed to better identify the paths that lead toward equality. Arguing that agency should be detached from emancipatory politics does not mean that we should abandon the ideals of justice, legitimize patriarchy or opt for cultural relativism.. Recent evidence from India highlights the contrast between the failures of women's collective action promoted by microfinance and the success of fundamentalist movements in mobilising women (Batliwala and Dhanraj 2007; Sen 2007). By recognizing women's multiple identities, desires and constraints, these fundamentalist movements have enabled women to take on new forms of public responsibilities, to enter public spaces and even to challenge certain patriarchal practices (Sen 2007). This apparent paradox, whereby it seems that women feel the most "empowered" within conservative, patriarchal movements, calls for profound reflection on how should we approach and conceptualise freedom in contexts where, as stated by Saba Mahmood, "submission to certain forms of (external) authority is a condition for achieving the subject's potentiality" (Mahmood 2005: 31). If we are more aware of women's desires, aspirations and constraints in diverse contexts, we can better figure out what motivates women's cooperation and "sisterhood" in contrast to conflict and competition.

\section{List of references}

Abrams, K. A. (1999) From Autonomy to Agency: Feminist Perspectives on Self-Direction, 40 William. \& Mary Law Review, 40(3): 804-847.

Agier, I. \&Szafarz, A. (2010) Microfinance and Gender: Is There a Glass Ceiling in Loan Size? UniversitéLibre de Bruxelles, Working Papers CEB 10-047.

Ackerly, B.A. (1995), Testing the Tools of Development: Credit Programmes, Loan Involvement and Women's Empowerment, IDS Bulletin, 26 (3): 56-68. 
Guérin I. Kumar S. Agier I. Women's empowerment: power to act or power over other women? Lessons from Indian microfinance, Oxford Development Studies, 41(1): S76-S94.

Agarwal, B. (1994), A field on one's own. Gender and land rights in south Asia, Cambridge: Cambridge University Press.

Allen, A. (2005) Feminist Perspectives on Power, Stanford: Stanford Encyclopedia of Philosophy. On line document.http://plato.stanford.edu/entries/feminist-power/ (last access 15th July, 2010).

Armendariz, B. \&Labie, M. (eds) (2011) Handbook of Microfinance, Washington: World Scientific Publishing.

Augsburg, B. \&Fouillet, C. (2010) Profit Empowerment: The Microfinance Institution's Mission Drift. Perspectives on Global Development and Technology [Special Issue: Microfinance and Institutions], 9 (3-4): 327-355.

Banerjee, A, \&Duflo, E. (2011) Poor economics: a radical rethinking of the way to fight against poverty, NewYork: Public Affairs.

Basu, A., (éd.) 1995, The Challenges of Local Feminisms. Women's Movements in Global Perspective, Boulder, San Francisco andOxford : Westview Press.

Batliwala, S. \&Dhanraj, D. (2007) Gender myths that instrumentalize women: a view from the Indian front line, in Cornwall A., Harrison E., \&Whitehead A., (eds) Feminisms in development. Contradictions, contestations and challenges, London/New-York: Zed Book, pp. 21-35

Béteille, A. (1999) Empowerment, Economic and Political Weekly vol. XXXIV, n¹0-11.

Ciotti, M.(2009) The conditions of politics: Low-caste women and political agency in a northern Indian city', Feminist Review 91: 113-134.

Collins, D.,Morduch, J., Rutherford, S., \&Ruthven, O. (2009).Portfolios of the Poor: How the World's Poor Live on $\$ 2$ a Day, Princeton: Princeton University Press.

Cornwall, A. (2007) Myths to live by? Female Solidarity and Female Autonomy Reconsidered, Development and Change 38(1): 149-168.

Cornwall, A., Harrison, E., \& Whitehead, A. (2007) Gender Myths and Feminist Fables: The Struggle for Interpretive Power in Gender and Development, Development and Change 38(1): 1-20.

D’Espallier B., Guérin I., \&Mersland R (2011) Women and repayment. A global analysis, World Development, 39(5): 758-772. 
Guérin I. Kumar S. Agier I. Women's empowerment: power to act or power over other women? Lessons from Indian microfinance, Oxford Development Studies, 41(1): S76-S94.

Dreze, J. (1990) Poverty in India and the IRDP disillusion, Economic and Political Weekly, Sept 29.

Fernando, J. (2006) (ed) Microfinance. Perils and Prospects, Routledge: Londres.

Fouillet, C. (2010) "Banking sector reforms, microfinance and safety net: Evidence from India", Contribution to the Workshop on Microfinance's contribution to development studies. What interdisciplinary approaches add to microfinance understanding?, University of Oxford/Universitélibre de Bruxelles, January 14-15.

Ghate, P. (2007) Indian microfinance. The challenges of rapid growth, New-Delhi: Sage.

Garikipati, S. (2008). The impact of lending to women on household vulnerability and women's empowerment: evidence from India, World Development 36(12): 2620-2642

Goetz, A., \& Gupta, R. S. (1996) Who takes the credit? Gender, power and control over loan use in rural credit programs in Bangladesh. World Development, 24(1): 45-63.

Grasmuck, S., \&Espinal, R. (2000), Market Success or Female Autonomy?Income, Ideology and Empowerment among Micro-entrepreneurs in the Dominican Republic, Gender and Society, vol. 14, n², April, pp. 231-255.

Guérin, I. (2011). Do women need specific microfinance services? InArmendariz, B.,\&Labie, M. (eds) Handbook of Microfinance, Washington: World Scientific Publishing, pp. 420432.

Guérin, I. (2006) Women and Money: multiple, complex and evolving practices, Development and Change, 37(3), May: 549-570.

Guérin, I. \& Palier, J. (eds), (2005), Microfinance challenges: Empowerment or disempowerment of the poor?, Pondicherry (India) : IFP, coll. Sciences Sociales $N^{\circ} 10$.

Guérin, I., Roesch.M., Venkatasubramanian, G., \& D’Espallier, B. (2012) Credit from whom and for what? Diversity of borrowing sources and uses in rural South-India, Journal of International Development, 24: 122-137.

Guérin, I., Morvant-Roux, S., \& Villarreal M. (2013), Microfinance, debt and overindebtedness. Juggling with money, London: Routledge..

Harriss-White, B. \&Colatei D. (2004) Rural credit and the collateral question, in Harriss-White \& Janakarajan (eds) Rural India facing the $21^{\text {st }}$ century. Essays on long term change and recent development policy, London: Anthem South Asian Studies 
Guérin I. Kumar S. Agier I. Women's empowerment: power to act or power over other women? Lessons from Indian microfinance, Oxford Development Studies, 41(1): S76-S94.

Harriss-White, B. (2003) India Working. Essays on Society and Economy, Cambridge : Cambridge University Press.

Hashemi, S., Schuler, S., \& Riley, A. (1996) Rural credit programs and women's empowerment in Bangladesh.World Development, 24(4), 635-654.

Hudon, M. (2008) Norms and values of the various microfinance institutions, International Journal of Social Economics, 35(1): 35-48.

Jauzelon, C. (2007) Microfinance et pratiques sociales des femmes paraiyars en Inde du sud : solidarité « organisée » ou solidarité « héritée »? Revue Tiers Monde, 2(190) : 275-289.

Johnson, S., (2005). Gender relations, empowerment and microcredit: moving from a lost decade, The European Journal of Development Research, 17 (2): 224-48.

Johnson, S., \&Rogaly, B., 1997.Microfinance and poverty reduction, Oxford: Oxfam.

Kabeer, N (2010) Gender and social protection strategies in the informal economy, London/New-York/New-Delhi: Routledge.

Kabeer, N. (2001) Conflicts Over Credit: Re-evaluating the Empowerment Potential of Loans to Women in Rural Bangladesh, World Development 29(1): 63-84.

Kabeer, N. (1999), Resources, Agency, Achievements: Reflections on the Measurement of Women's Empowerment, Development and Change, 30: 435-464.

Kalpana, K. (2008) The Vulnerability of 'Self-Help': Women and. Microfinance in South India', Working Paper 303, Institute of Development Studies, April.

Kandiyoti, D., (1988) Bargaining with Patriarchy, Gender and Society, vol. II, no 3, pp. 274290.

Kapadia, K., (1996), Siva and her Sisters. Gender, Caste and Class in Rural South India, New Delhi : Oxford University Press.

Krishnan, S. (Jan 2005). Gender, caste, economic inequalities and marital violence in rural South India. Health Care for Women International, 26 (1):87-99.

Mahmood, S. (2005) Politics of Piety. The Islamic revival and the feminist subject, Princeton and Oxford: Princeton University Press.

Mayoux, L. (1999) Questioning virtuous spirals: microfinance and women's empowerment in Africa. Journal of International Development, 11(7): 957-984. 
Guérin I. Kumar S. Agier I. Women's empowerment: power to act or power over other women? Lessons from Indian microfinance, Oxford Development Studies, 41(1): S76-S94.

Mayoux, L. (2001) Tackling the Down Side: Social Capital, Women's Empowerment and Micro-Finance in Cameroon, Development and Change 32(3): 421-50.

Mencher, J. P. (1988), Women's Work and Poverty : Women's Contribution to Household Maintenance in South India, in : Bruce et Dwyer (eds), A Home Divided : Women and Income in the Third World, Stanford : Stanford University Press, pp. 99-119.

Mohanty, Ch. (1988) Under Western Eyes: Feminist Scholarship and Colonial Discourses, Feminist Review, 30: 61-88.

Montgomery, R., (1996) Disciplining or protecting the poor: avoiding the social costs of peer pressure in microcredit schemes, Journal of International Development, 8(2): 289-305.

Montgomery, R., Bhattacharya D., \&Hulme H. (1996). Credit for the Poor in Bangladesh: The BRAC Rural Development and Employment Programme. In Hulme\& Mosley (eds) Finance against Poverty, vol. 2,, New York: Routledge.

Molyneux, M. (1985) Mobilization without Emancipation? Women's Interests, the State, and Revolution in Nicaragua, Feminist Studies, 11 (2): 227-254

Molyneux, M. (2002) Gender and the silences of social capital, Development and Change, 33 (2): $167-188$.

Mouffe, Ch. (1995) Feminism, Citizenship and Radical Democratic Politics in Nicholson, L.\&Seidman, S. (eds)Social Postmodernism: Beyond Identity Politics Cambridge: Cambridge University Press, pp. 315-331.

Olsen, W.K. \&Morgan, J. (2010). Aspiration Problems in Indian Micro-Finance: A Case Study Exploration. Journal of Developing Societies, (26): 415-454.

Oxaal, Z. \& Baden S. (1997) Gender and empowerment: definitions, approaches and implications for policy, Brighton (UK): BRIDGE (development - gender) / Institute of Development Studies.

Pattenden, J. (2010) A neo-liberalisation of civil society?Self-help groups and the labouring class poor in rural south-India, Journal of Peasant Studies 37 (3); 485-512.

Pitt, M. \&Khandker, S.R. (1996), Household and Intra-Household Impacts of the Grameen Bank and Similar Targeted Credit Programs in Bangladesh, World Bank Discussion Papers 320, Washington, DC.

Rahman, A. (1999) Women and Microcredit in Rural Bangladesh: An Anthropological Study of Grameen Bank Lending. Boulder, CO: Westview Press. 
Guérin I. Kumar S. Agier I. Women's empowerment: power to act or power over other women? Lessons from Indian microfinance, Oxford Development Studies, 41(1): S76-S94.

Rankin, K. N. (2002), Social capital, microfinance and the politics of development, Feminist Economics, 8 (1):1-24.

Rao, A. (ed) (2003), Gender and Caste, New Delhi: Kali for women.

Ravindran, S. TK. (1999). Female autonomy in Tamil Nadu.Unravelling the complexities, Economic and Political Weekly, April 17-24.

Razavi, R. (2009) Engendering the political economy of agrarian change, Journal of Peasant Studies, 36(1): 197-226.

Rowland, J. (1995) Empowerment Examined, Development in Practice, 5(2): 101-107.

Sa-Dhan (2009) The Bharat Microfinance Report-Quick Data 2009, New-Delhi: Sa-Dhan.

Sen, A. (2007) Shiv Sena Women. Violence and Communalism in Bombay Slum, Bloomington and Indianapolis: Indiana University Press.

Servet, J.-M. (2006), Banquiers aux pieds nus, Paris, Odile Jacob.

Srinivasan, N., 2009, Microfinance in India. State of the report 2008, New-Delhi et Thousand Oaks (CA) : Sage, xvi, 155 p.

Townsend, J G., Zapata, E,.Rowlands, J., Alberti, P.,\& Mercado, M. (1999) Women and Power: Fighting Patriarchies and Poverty. London: Zed Book.

Weber, H. (2006) "The global political economy of microfinance and poverty reduction: locating local 'livelihoods' in political analysis" in Fernando (ed) op. cit.: 43-64.

Wright, K. (2006), The darker side to microfinance: evidence from Cajamarca, in Fernando (éd.), 154-171.

Yogendra B. S., \&Rankin K. N. (2010) The Politics of Subversion in Development Practice: An Exploration of Microfinance in Nepal and Vietnam, Journal of Development Studies, 44 (8): $1214-1235$. 